\title{
Modeling Sediment Yield-Case Study Guder Watershed, Blue Nile Basin, Central Ethiopia
}

\author{
Gonfa Erena*, Dereje Adeba \\ Wollega Institute of Technology, Wollega University, Oromia, Ethiopia \\ Email address: \\ Erenagonfa@gmail.com (G. Erena) \\ ${ }^{*}$ Corresponding author
}

\section{To cite this article:}

Gonfa Erena, Dereje Adeba. Modeling Sediment Yield-Case Study Guder Watershed, Blue Nile Basin, Central Ethiopia. American Journal of Civil Engineering. Vol. 9, No. 2, 2021, pp. 39-46. doi: 10.11648/j.ajce.20210902.12

Received: February 9, 2021; Accepted: March 24, 2021; Published: April 23, 2021

\begin{abstract}
Guder watershed is one of the watershed found in Blue Nile basin, central Ethiopia, mostly eroded area due to the widespread of agricultural land. This study is based on the Soil and Water Assessment Tool (SWAT) model interface of GIS environment to simulate sediment yield of the watershed at outlet. The stream flow was calibrated for ten years (1996-2005) and validated for seven years (2006-2012) at Guder gauging station using SWAT-CUP to check performance of the model. The model performance has been evaluated by using statistical parameters of coefficient of determination $\left(\mathrm{R}^{2}\right)$ and Nash-Sutcliffe simulation efficiency (NSE) 0.92 and 0.80 respectively for calibration. Model validation results 0.83 and 0.65 for $\mathrm{R}^{2}$ and NSE, respectively. Both calibration and validation results indicate that the measured values show good agreement with simulated flow. Sediment yield from each sub watershed were determined and prone soil erosion areas has been identified for management planning.
\end{abstract}

Keywords: Modeling, Guder Watershed, Sediment Yields, Soil Erosion, SWAT-CUP

\section{Introduction}

\subsection{General Background}

The main problem in our country's economy is highly based on smallholder agriculture which is seriously affected by soil erosion. The severity of soil erosion is caused due to the both of natural effects such as aggressive climate, steep topography and erodible soil type and human activities such as land clearing for agriculture and particularly overgrazing, firewood stripping has resulted in a rapid acceleration of soil erosion [15]. Currently, the natural resources of the study area especially land and water are adversely affected by the rapidly growing population. The rising demand for agricultural land, which has further worsened the soil erosion and deforestation.

Watershed management has been conducted in Ethiopia by different local, state and private organizations over a range of scales by different techniques. But, there is a very small hydrological model apply, which supports to explore the hydrological process occur within the watershed. It is also important for planning and managing water resources and land degradation. The most powerful ineffective watershed management and planning are assessing spatially and temporal variability of the magnitude and intensity of sediment yield for recommend and designs of appropriate soils and water conservation measures [5].

\subsection{Statement of the Problem}

Guder watershed is one of the highlands within Blue Nile basin with steep and long slope topography which believed to trigger soil erosion problem [8]. Many farmers in this area cultivate on sloppy and hilly land that causing topsoil to be washed away while the rainy season. High rainfall cause erosion and associated sedimentation, increasing the cost of operation, maintenance and shortening the life span of hydraulic structure [16].

The problem of land degradation due to poor land management is a danger for the reservoir and lower parts of the study areas. It generate high runoff discharges and imposing huge sediment yield, which may result in reducing the water storage capacity of the dam. Land degradation is expected to have adverse impacts on hydropower reservoir and socio-economic development globally. The degree of the 
impact will vary across nations and it may have far-reaching implications to Ethiopia for various reasons. It mainly as its economy largely depends on agriculture [6]. There is also a damaging effect due to sediment transport by runoff at watershed and stream morphology [2].

\subsection{Objective of the Study}

1) To determine sediment yield from the watershed.

2) Assess the temporal and spatial variability sediment yield in the watershed.

3) To identify the most erodible sub-watershed.

\section{Materials and Methods}

\subsection{Description of Study Area}

Guder watershed which has a drainage area of $7011 \mathrm{~km}^{2}$ situated in central Ethiopia; in the southeastern part of Blue Nile basin. It is found in Oromia regional state between $7^{\circ} 30^{\prime}$ to $9^{\circ} 30^{\prime} \mathrm{N}$ latitudes $37^{\circ} 00^{\prime}$ to $39^{\circ} 00^{\prime} \mathrm{E}$ longitudes. Guder watershed covers 11 weredas; Tikur Incinis, Ambo, Cheliya, Dendi, Jima Rare, Mida Kegn, Gojo, Guduru, Liban Kutaye, Tokke Kutaye, and Ababo Guduru (Figure 1). It borders with the Muger sub-basin to the east, the Awash basin to the south and Fincha sub-basin to the west. The Guder river originates from the mountainous area of the south of the towns of Ambo and Guder. The river flows from the south to the north and has its outlet to the Abbay River. The main tributaries of Guder river include Tarantar and Dabissa.

\subsection{Tools and Methods}

The main tools and datas used for input data preparation and analysis were: Arc SWAT, SWAT-CUP, PCPSTAT, Dew02.exe, DEM, Meteorological data, Hydrological data, land use land cover map and data, soil map and data.

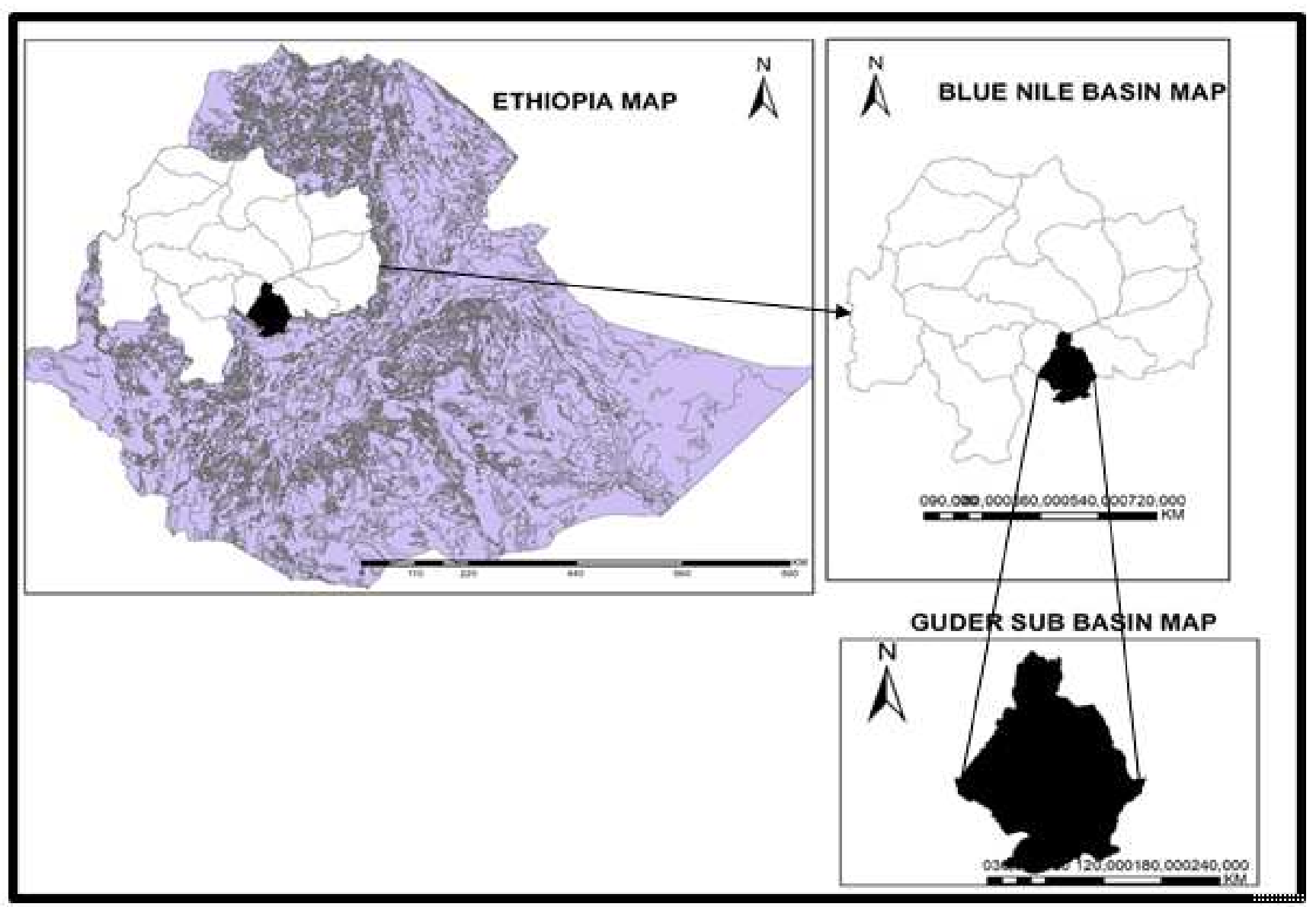

Figure 1. Location of study area.

\subsection{SWAT Model Description}

SWAT is the link for Soil and Water Assessment Tool, a river basin, or watershed, scale model developed by Dr. Jeff Arnold. SWAT was used to predict the impact of land management practices on water, sediment and agricultural chemical yields in large complex watersheds with varying soils, land use, and management conditions over long periods.

\subsection{Hydrological Component}

The most hydrological process simulated by SWAT model [18]: are evapotranspiration (ET), surface runoff, infiltration, 
percolation, shallow aquifers, and deep aquifers flow, channel routing [3]. In SWAT, the impacts of spatial and temporal variations in topography, land use, soil and other watershed features on hydrology are considered in classifications. It is simulated based on the water balance equation

$$
S W_{t}=S W_{o}+\sum_{i=1}^{t}\left(R_{\text {day }}-Q_{\text {surf }}-E_{a}-W_{\text {seep }}-Q_{g w}\right)
$$

Where, $\mathrm{SW}_{t}$ : is the final soil water content day, $\mathrm{SW}_{o}$ : is the initial soil water content on day, $\mathrm{R}_{d a y}$ : is the amount of precipitation on day, $\mathrm{Q}_{\text {surf }}$ : the amount of surface runoff on a day, $\mathrm{E}_{a}$ : the amount of evapotranspiration on day, $\mathrm{W}_{\text {seep }}$ : the amount of water entering the vadose zone from the soil profile on a day, $\mathrm{Q}_{g w}$ : return flow on day

\subsection{Surface Runoff Component}

SWAT uses two methods for calculating surface runoff; the modified SCS curve number method [17] and the Green \& Ampt infiltration method [13]. The modified SCS curve number used to determine runoff depth by:

$$
Q_{\text {surf }}=\frac{\left(R_{\text {day }}-0.2 S\right)^{2}}{\left(R_{\text {day }}+0.8 S\right)}
$$

Where

$$
\begin{gathered}
\mathrm{I}_{a}=0.2 \mathrm{~S} \\
S=25.4 *\left(\frac{100}{C N}-10\right)
\end{gathered}
$$

$\mathrm{CN}$ is the curve number for the day, The initial abstractions, $\mathrm{I}_{a}$ and $\mathrm{Q}_{\text {suf }}$ is the accumulated runoff or rainfall excess.

\subsection{Sediment Yield Component}

SWAT computes sediment for each HRU caused by rainfall and runoff with the Modified Universal Soil Loss Equation (MUSLE)

$$
\text { Sed }=11.8 *\left(Q_{\text {suf }} * q_{\text {peck }} * A_{\text {mu }}\right)^{0.56} * K_{\text {sole }} * C_{\text {sde }} * P_{\text {ssle }} * L S_{\text {ssle }} * \text { FRG }
$$

Where, Sed is the sediment yield on a given day in metric tons, $Q_{\text {suf }}$ is the surface Runoff from the watershed in $\mathrm{mm} / \mathrm{ha}, q_{\text {peak }}$ is the peak runoff rate in $\mathrm{m}^{3} / \mathrm{s}, A_{h r u}$ is an area of hydrologic response units in ha, $K_{\text {usle }}$ is the USLE soil erodability factor, $C_{u s l e}$ is the USLE land cover and management factor, $P_{u s l e}$ is the USLE support practice factor, $L S_{u s l e}$ is the USLE topographic factor, and CFRG is the coarse fragment factor.

\subsection{Sediment Data}

Data acquirement for sediment is widely a problem to assess long term sediment yield of the watershed, to know the amount sediment loaded to the river. To identify and undertake management scenario changes in river slope \& plan formation it is essential to get raw data of suspended sediment concentrations $(\mathrm{mg} / \mathrm{l})$ for the selected station. Sediment rating curve describes the mean relation between stream flow and suspended sediment concentration for a watershed [4]. The sediment rating curve is usually expressed as a power function of discharge (Figure 2).

$$
q_{s}=0.0867 * \mathrm{C} * \mathrm{Q}
$$

Where: $q_{s}$ is suspended sediment load, Q is the discharge $\left(\mathrm{m}^{3} / \mathrm{s}\right)$, Cis suspended Sediment concentration and 0.0867 conversion factor.

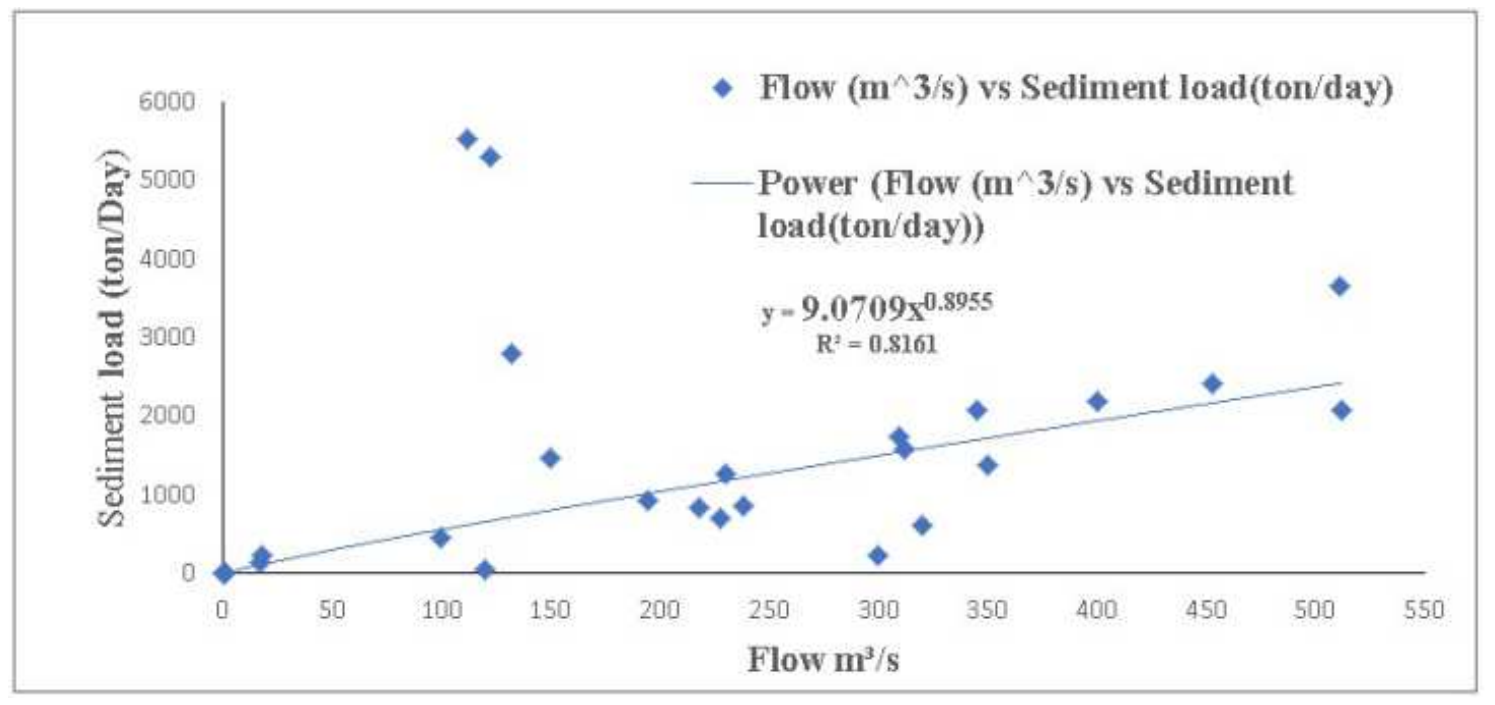

Figure 2. Sediment flow rating curve for gauging station. 


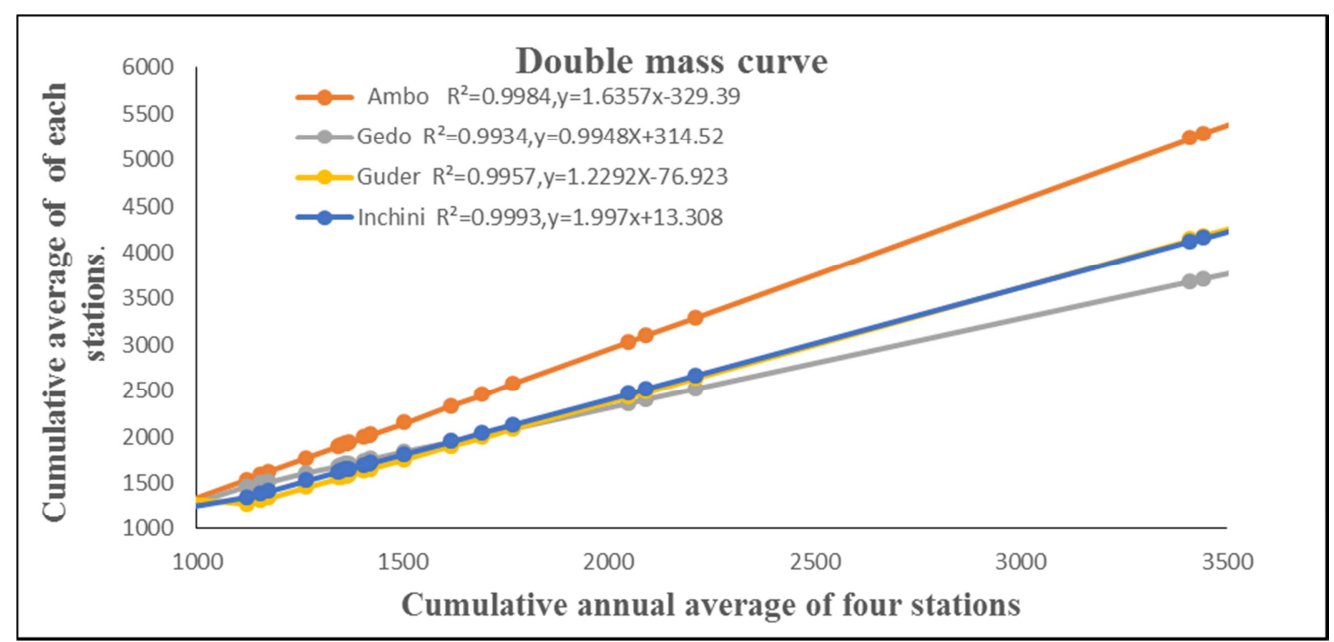

Figure 3. Consistency checking for the precipitation within and around the watershed.

\subsection{Input Data Collection}

The meteorological required data for swat were daily precipitation, maximum and minimum temperature, relative humidity, wind speed, solar radiation collected from Ethiopian meteorological service agency at different stations. The spatially data digital elevation model (DEM), land use/land cover map, soil map and data were collected from different sources. The daily stream data for calibration and validation of the SWAT model were collected from Ethiopian ministry of water, irrigation and energy bureau.

\subsection{Data Analysis and Processing}

The meteorologically data and temperature of all gauging stations (Guder, Ambo, Inchini and Gedo) were prepared in text format.

Because input data contain lacks the quality and quantity data as well as missing data computation method was very important. For detecting inconsistency of daily precipitation, to correct and adjust raw data was checked by double mass curve method as shown (Figure 3).

\subsection{Simulation and Evaluation of Model Performance}

The simulated files imported to the database to be saved with a unique remembered name. SWATCUP is used for sensitivity analysis, calibration and validation.

The calibration and validation of SWAT model is evaluated using statistical measures. Coefficient of determination $\left(\mathrm{R}^{2}\right)$ is one of the statistical indicator of simulated compared to observed data. $\mathrm{R}^{2}$ ranges with higher value the more approach to 1 indicating better agreement and value less than 0.5 indicates a poor performance of the model [14]

$$
R^{2}=\frac{\left[\sum_{i=1}^{n}\left(q_{s i}-\overline{q_{s}}\right)\left(q_{o i}-\overline{q_{o}}\right)\right]}{\sum_{i=1}^{n}\left(q_{s i}-\overline{q_{s}}\right)^{2} \sum_{i=1}^{n}\left(q_{o i}-\overline{q_{o}}\right)^{2}}
$$

Where: $q_{s i}$ is the simulated flow, $q_{o i}$ is observed flow $q_{o}$ and $\overline{q_{s}}$ is the average simulated and observed flow.

Nash-Sutcliffe simulation efficiency (NSE): NSE measures the degree of fitness of the observed and simulated data variance. It generally ranges from $-\infty$ to 1 . The more the NSE approaches to 1, indicates the better will be the model performance [9]:

$$
N S E=1-\frac{\sum_{i=1}^{n}\left(q_{o i}-q_{s i}\right)^{2}}{\sum_{i=1}^{n}\left(q_{o i}-\overline{q_{o}}\right)^{2}}
$$

Where, $q_{s i}$ is the simulated flow, is observed flow, $\overline{q_{o}}$ is mean observed flow.

\section{Result and Discussion}

\subsection{Modeling of Stream Flow}

The modeling of streamflow was calibrated and validated with a time series dataset of 19 years from 1994 to 2012. The first two years of the modeling period were used for 'model warm-up. Data for the period 1996 to 2005 were used for calibration and 2006-2012 for validation.

\subsection{Sensitive Parameter}

Identifying sensitive parameters enables us to focus only on parameters that affect most the model result [1]. The 23 parameters were used in sensitivity analysis for flow calibration. The identification of a significant parameter is using p-value and t-Stat. A p-value close to zero and the largest absolute value of t-stat is more sensitive [12]. Out of these parameters only seven of them, which have greatest influence on model output are CN2, HRU_SLP, GW_DELAY, ALPHA_BNF, ESCO, CH_N2, CH_K2, were selected as parameters for calibration process.

\subsection{Model Calibration}

The statically calibration model performance, the 
simulated average monthly flow matched well with the average monthly measured flow (with $\mathrm{R}^{2}=0.92$, NSE $=0.80$ ). The visual comparison of graphs also other measures of the model performance during calibration for stream flow (Figure 4 and Figure 5) which is important to identify model similarity and variation.

FLOW_OUT_1

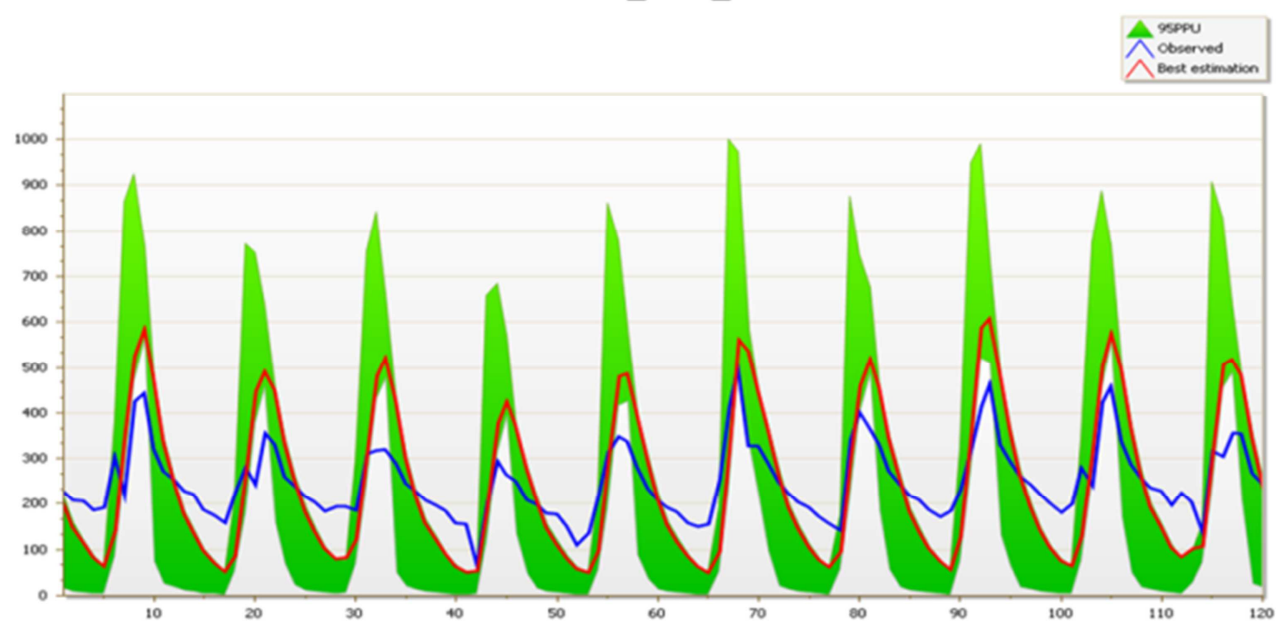

Figure 4. Simulated and observed average monthly streamflow generated from SWAT CUP.

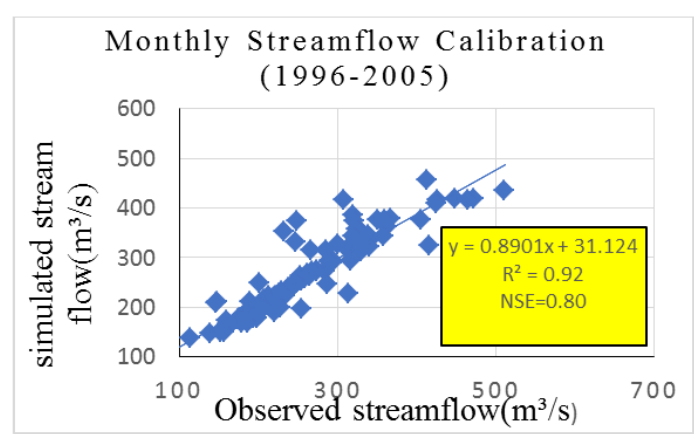

Figure 5. Scatter plot of the simulated versus measure mean monthly streamflow during calibration period.

\subsection{Model Validation}

Flow validation was carried out from January 2006 to December 2012, without further adjustment of the parameters of flows. The hydrograph for the validation period of the observed and simulated flow is in a monthly base estimation.
For this study, monthly validation of statistical analysis showed that good agreement between observed and simulated stream flow, which was explained by $\mathrm{R}^{2}$ and NSE values $(0.81$ for $\mathrm{R}^{2}$ and 0.65 for NSE) (Figure 6 and Figure 7).

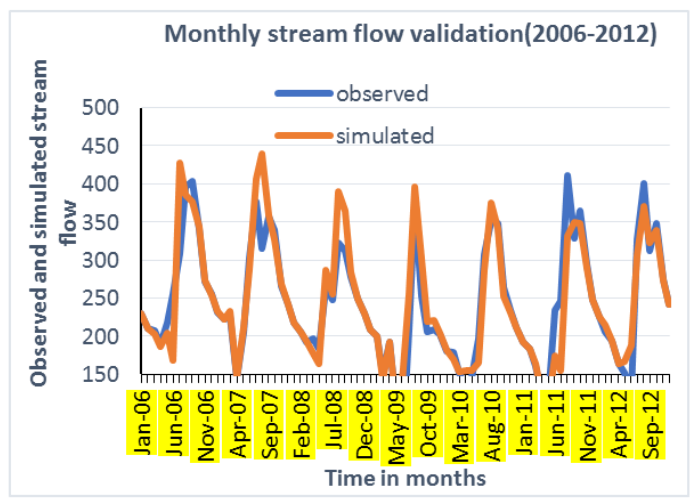

Figure 6. Validation results of mean monthly measured simulated streamflow (2006-2012).

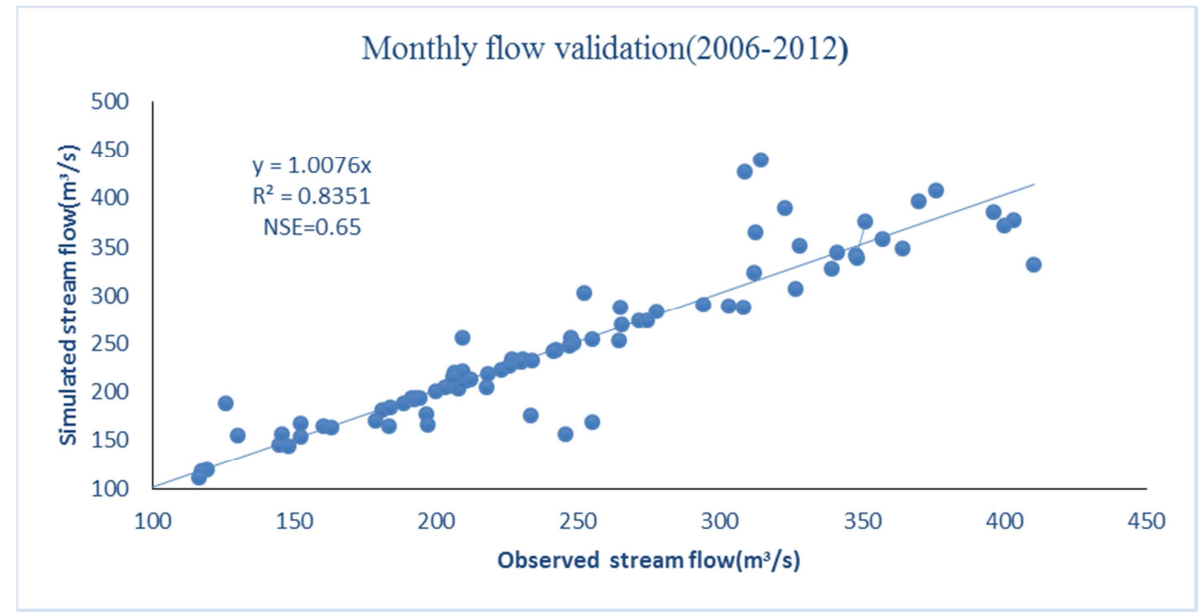

Figure 7. Scatter plot of simulated versus measured monthly streamflow during the validation period (2006-2012). 


\subsection{Calibration and Validation of Sediment Yield}

The calibration and validation of the simulated sediment yield of the model resulted by developing a rating curve based on the measured sediment data. The model also showed good result in predicting the average monthly sediment yields in the study area with $\mathrm{R}^{2}$, NSE, and values of $0.78,0.69$ respectively during calibration. The annual average suspended sediment generated from the sediment rating curve and the simulated annual average sediment yield by the model was more closely related with $19.1 \mathrm{t} / \mathrm{ha} / \mathrm{yr}$ and $21.02 \mathrm{t} / \mathrm{ha} / \mathrm{yr}$ respectively.
The overall simulated result of sediment yield can be used for further application. Most eroded areas were identified through the watershed. As can be seen from Table 1 and Figure 8, the minimum sediment yield recorded in the period of 1999 but after the next ten years in 2009 they are highly increased. The main reason for the increment of runoff and sediment yield is widely spread of cultivated lands rather pastoral land and uneven distribution of rainfall intensity through the time. Temporal variation of mean annual surface runoff and sediment yield ranges between $35.53 \mathrm{~mm}$ to $76.19 \mathrm{~mm}$ and $10.94 \mathrm{ton} / \mathrm{ha} / \mathrm{yr}$ to $27.14 \mathrm{ton} / \mathrm{ha} / \mathrm{yr}$ for the simulated year.

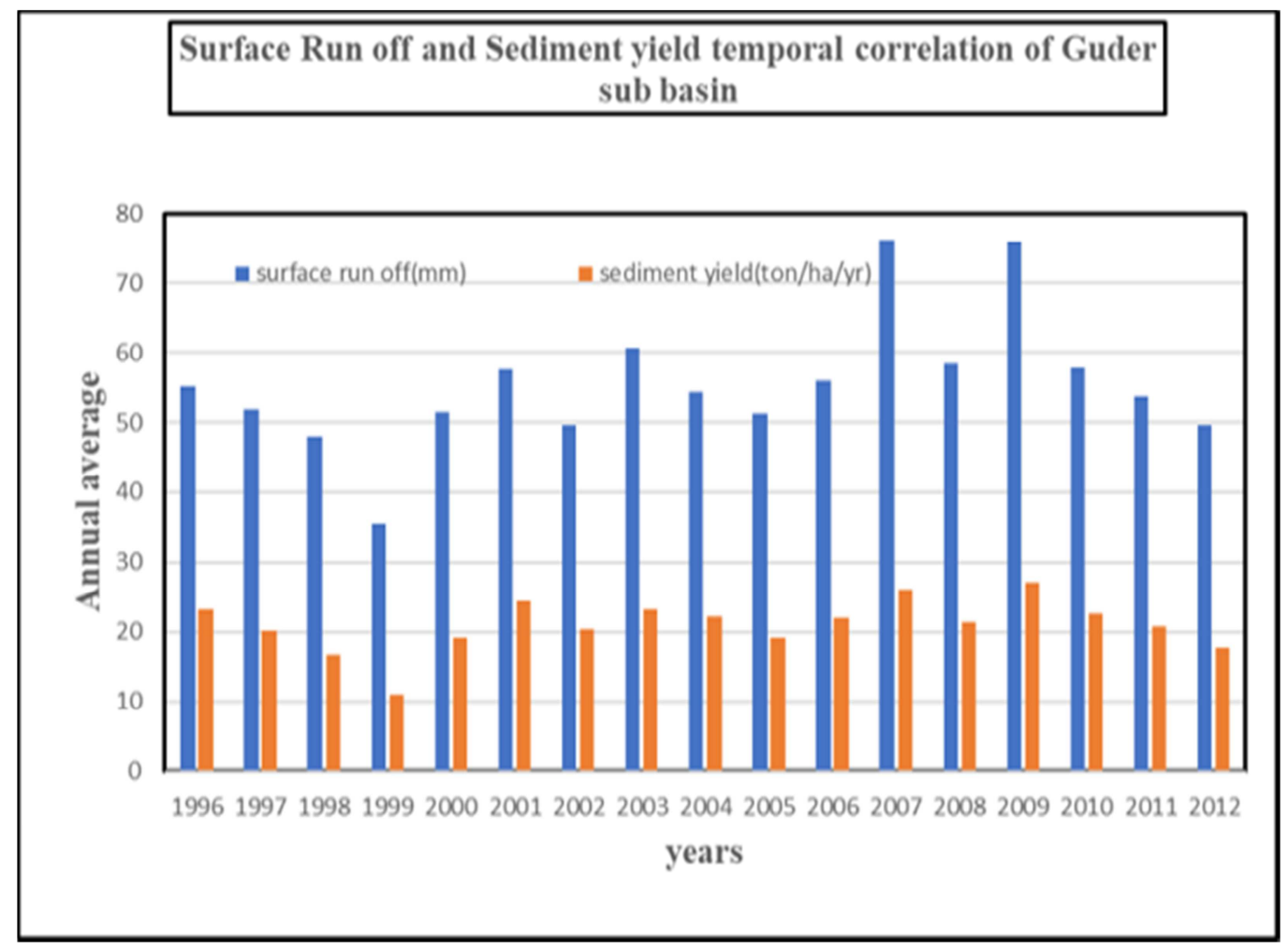

Figure 8. Temporal variation of Runoff and Sediment yield hectograph.

Assessment of the spatial variability of sediment yield is important for watershed management planning and identifying the most erodible catchment [7]. Identification and ranking of critical erosion-prone areas is also very important mainly for policymakers to implement best management strategies that are more sustainable in the future for long term used [10]. Figure 9 show the spatial distribution of sediment yield in the Guder watershed whereas, Table 2 shows the rank category of erosion-prone areas. The maximum annual sediment yield is generated in the sub-basin $\mathrm{N}-9$ and the minimum annual sediment yield is generated in the sub-basin N-15. This result shows that there is some subbasin which are vegetated enough. On the other hand, the most erodible area is not vegetated enough and needs rehabilitation. The whole spatial average annual surface runoff and sediment yield distribution through the watershed ranges from $38.9 \mathrm{~mm}$ to $68.46 \mathrm{~mm}, 0.33 \mathrm{ton} / \mathrm{ha} / \mathrm{yr}$ to $55.33 \mathrm{ton} / \mathrm{ha} / \mathrm{yr}$ respectively.

Table 1. Spatial variation of sediment yield of Guder watershed.

\begin{tabular}{llll}
\hline Sub basin by name & Sediment yield (ton/ha/yr.) & Sub basin by name & Sediment yield (ton/ha/yr.) \\
\hline N-1 & 17.82 & N-9 & 55.31 \\
N-2 & 5.32 & N-10 & 43.84 \\
N-3 & 16.37 & N-11 & 0.35 \\
N-4 & 20.52 & $\mathrm{~N}-12$ & 12.04 \\
N-5 & 20.09 & $\mathrm{~N}-13$ & 0.59 \\
N-6 & 6.59 & $\mathrm{~N}-14$ & 40.67 \\
N-7 & 30.11 & $\mathrm{~N}-15$ & 0.33 \\
N-8 & 37.50 & $\mathrm{~N}-16$ & 28.90 \\
\hline
\end{tabular}




\subsection{Ranking and Mapping of Sediment Yield Source Area}

The highest sediment yield sub-basin areas are those which are covered with cultivated land and low erosion was observed in the pastoral covers. The hydrologic response unit distribution for the selected sub-basins clearly indicates the land cover of cultivated land is the major controlling factor for sediment potential areas. A study of soil formation rates in a different agro-ecological zone of Ethiopia indicates that the range of the tolerable soil loss level for the various agroecological zones of Ethiopia was 2 to $18 \mathrm{t} / \mathrm{ha} / \mathrm{yr}$ [11]. It is assigned depending on their annual average sediment yield as low 0 to $6 \mathrm{t} / \mathrm{ha} / \mathrm{yr}$, moderate 6 to $12 \mathrm{t} / \mathrm{ha} / \mathrm{yr}$, high 12 to 18 $\mathrm{t} / \mathrm{ha} / \mathrm{yr}$ and severe above $18 \mathrm{t} / \mathrm{ha} / \mathrm{yr}$. Liban kutaye contain subbasins $(50 \%$ of $\mathrm{N}-2, \mathrm{~N}-4, \mathrm{~N}-5$ and $50 \%$ of $\mathrm{N}-1)$, Guduru contain sub-basin $(50 \%$ of $\mathrm{N}-1,50 \%$ of $\mathrm{N}-2, \mathrm{~N}-3)$, cheliya contain sub-basin (N-9), Balami contain sub-basin (N-10), Jima rare contain sub-basin (N-7), Gojo contain sub-basin (N-8), Dandi contain sub-basin (N-12), Ambo contain subbasins $(\mathrm{N}-13, \mathrm{~N}-15)$, Inchini contain sub-basins $(\mathrm{N}-11, \mathrm{~N}-14$, $\mathrm{N}-16)$. The spatial distribution of sediment indicated that out of the total 16 sub-basin $(\mathrm{N}-11)$ sub-basins produce average annual sediment yields above 12 ton/ha/yr and the highest loading found in the southeast of Jibat and Roge mountains of West Shoa zone. Topography of the area was found to be the influential factor for eroded area rather than the existing surface runoff and precipitation for the study area. The greater steeper and long slope, more sever is the soil erosion that may occur. High steeper slope cause increased runoff velocity, and with this, the kinetic energy of water causes more erosion.

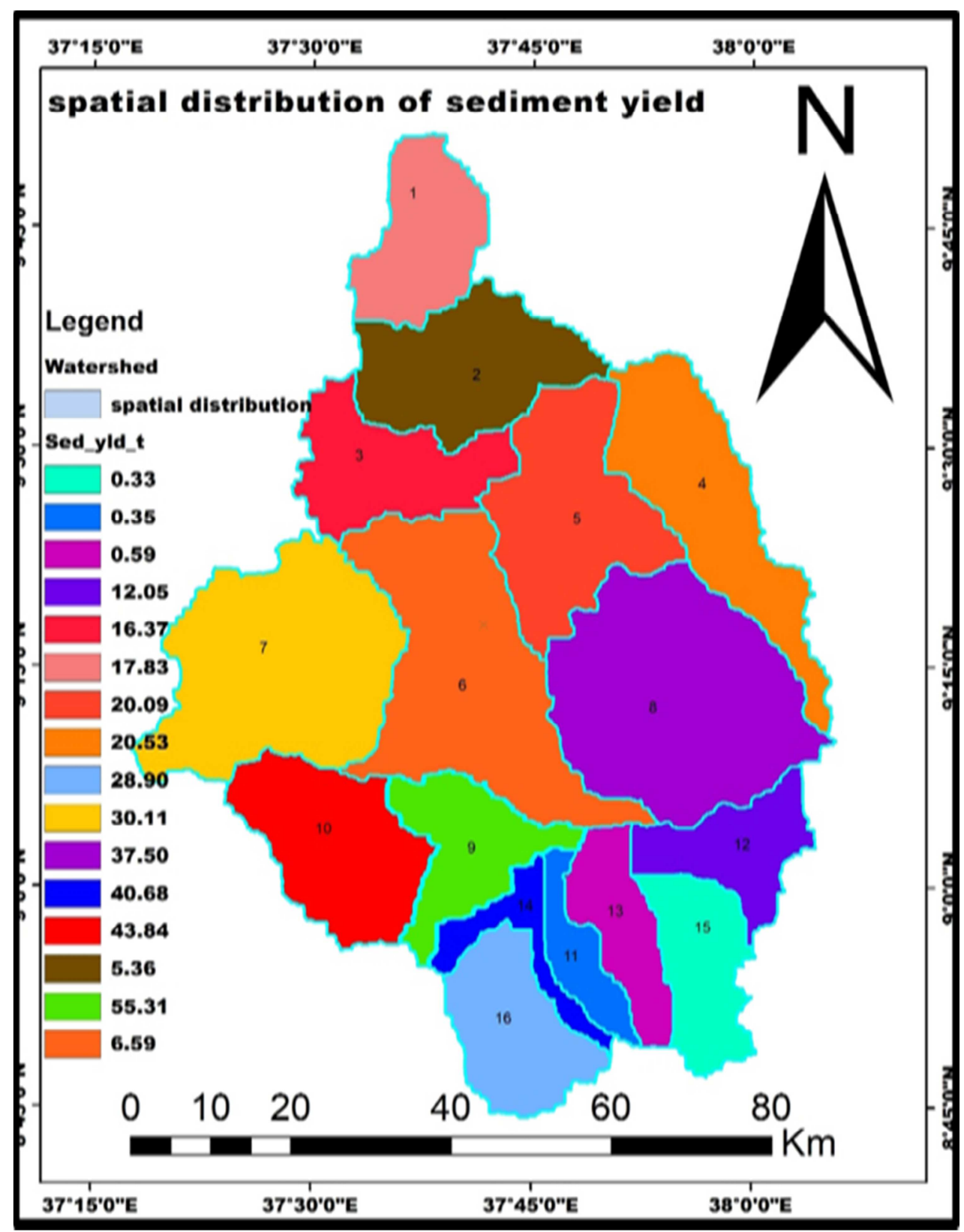

Figure 9. Spatial distribution of SWAT simulated annual sediment yield. 
Table 2. Percentage of severity to sediment yield for Guder watershed.

\begin{tabular}{llll}
\hline Range of sediment yield & Sub-basin & Areal coverage $\left(\mathbf{k m}^{\mathbf{2}}\right)$ & \% coverage \\
\hline Low & $2,11,13,15$ & 1853.35 & 26.45 \\
Moderate & 6 & 810.00 & 11.56 \\
High & $1,3,12$ & 910.40 & 12.99 \\
severe & $4,5,7,8,9,10,14,16$ & 3877.66 & 49.00 \\
\hline
\end{tabular}

\section{Conclusion}

This study was to model runoff and sediment yield by using current SWAT model version 2012, the model was evaluated by using different available input data from the watershed to attain the required objectives. Readily available spatial and downloaded data (DEM, Land use land cover, soil data) is collected from governmental agencies and combined using ArcGIS. The watershed parameters were derived from DEM resulting in 16-subbasins. Sub basins were further broken down into hydrological response units based on the land use and soil data.

In this study, attempts were made to characterize Guder watershed (large area of west Shoa) in terms of sediment yield, to evaluate the spatial and temporal distribution of sediment yield source areas, and identify hot spot areas (southeast of Jibat and Roge mountains) by using SWAT model. As a mitigation measure for the prevention of severs erosion and conservation mechanism, it is proposed to cover the mountainous and hilly area with plantation and control further degradation by erosion.

\section{References}

[1] Abbaspour, K., Johnson, A., and Genuchten. M. Th. (2007). Estimating Uncertain flow and transport parameters using a sequential uncertainty fitting procedure. Vadose Zone Journal 3 (4), 1340 - 1352.

[2] Abdi. B. (2014). Simulation of sediment yield using the SWAT model in Fincha watershed, Ethiopia. J. (Nat. Sci) 46, 283-297.

[3] Arnold. J. (2012). Large area of hydrologic Modeling of SWAT and assessment Part 1. Model development. Journal of the American water resource asses Association, 34: 73-89.

[4] Asselman. (2000). Fitting and interpretation of sediment rating curve. Journal of Hydrology, 234, 228-248.

[5] Betrie, G. B., Y. A. Mohammed, A. Van Griensven, and Srinivasan. (2011). Sediment yield modeling in the Blue Nile Basin using the SWAT model. Hydro. Earth science, 15, 807818.

[6] Dereje. T. (2015). Modeling Sediment yield using ARCSWAT and analyzing the most prominent remedial measures, case of
Melka Wakena reservoir. MSc thesis university of Addis Ababa, Ethiopia.

[7] Fasil. (2012). Prediction of Sediment inflow to Gefersa Reservoir (using SWAT Model) and Assessing sediment reduction methods).

[8] Fikadu. F. (2008). Establishing Rainfall-Run off-SedimentDischarge relationship in the Blue Nile. CP 19 project workshop proceedings, 112-131.

[9] Gassman P. W., Arnold J. G., Srinivasan R. and Reyes M. (2005). The worldwide use of the SWAT model: Technological driver, networking impacts, and simulation trends. Transactions of the ASABE.

[10] Habtamu, (2011). Watershed sediment yield modeling for data-scarce areas. Insitute of wasserbau university stuttgart.

[11] Hurni, H., Solomon, A., Amare, B., Berhanu, D., Ludi, E., Portner, B and Gete, Z. (1990). Land Degradation and asses sustainable land management in the highlands of southren Ethiopia.

$123-130$. https://www.researchgate.net/publication/265645925/

[12] Lenhart, T., K. Eckhardt, N. Fohrer, and H.-G. Frede. (2002). Comparison of two different approaches of sensitivity analysis. Physics and Chemistry of the Earth, 27: 645-654.

[13] Priestly, C., and Taylor, R. (1972). On the Assessment of Surface Heat Flux and Evaporation Using Larg- scale Parameters. Division of Atmospheric Physics, Commonwealth Scientific and Industrial Research Organization, Aspendale, Victoria, Australia. 1972.

[14] Santhi, C., R. Srinivasan, J. G. Arnold, and J. R. Williams. (2005). A modeling approach to evaluate the impacts of water quality management plans implemented in a watershed in Texas. Environmental Modeling \& Software, 21, 1141-1157.

[15] Sileshi, B. (2001). Investigation of water resources aimed at multi-objective development with respect to limited data situation: The case of Abbaya-Chamo Basin, Ethiopia. Thesis, Ph. D. Technical University of Dresden, Germany.

[16] Tamene, L., Park, S., Dikau, R., and Vlek, P. (2005). Analysis of factors affecting sediment yield variability in the highlands of Northern Ethiopia. Geomorphology, 76, 76-91.

[17] USDA SCS. (1972). National Engineering Handbook: part I and II Engineering Hydrology Washington, DC.

[18] Williams, J. (1985). In singh. v. p, editor, computer models of watershed hydrology. Water resource and asses publications Highland Ranch, co, 1995. 